\title{
Article \\ Study on Behavior of Some Perennial Flowering Species Used in Vertical Systems for Green Facades in Eastern European Climate
}

\author{
Mirela Cojocariu ${ }^{1}\left(\mathbb{D}\right.$, Elena Liliana Chelariu ${ }^{1, *} \mathbb{1}$ and Ciprian Chiruţă ${ }^{2}(\mathbb{D}$ \\ 1 Department of Horticultural Technologies, Faculty of Horticulture, “Ion Ionescu de la Brad” Iasi University of \\ Life Sciences, 700490 Iasi, Romania; mirela_c@uaiasi.ro \\ 2 Department of Exact Sciences, Faculty of Horticulture, "Ion Ionescu de la Brad" Iasi University of Life \\ Sciences, 700490 Iasi, Romania; kyru@uaiasi.ro \\ * Correspondence: julia@uaiasi.ro
}

check for updates

Citation: Cojocariu, M.; Chelariu,

E.L.; Chiruţă, C. Study on Behavior of Some Perennial Flowering Species Used in Vertical Systems for Green Facades in Eastern European Climate. Appl. Sci. 2022, 12, 474.

https://doi.org/10.3390/app12010474

Academic Editors: Stojan Kravanja and Pietro Picuno

Received: 10 October 2021 Accepted: 30 December 2021

Published: 4 January 2022

Publisher's Note: MDPI stays neutral with regard to jurisdictional claims in published maps and institutional affiliations.

Copyright: (C) 2022 by the authors. Licensee MDPI, Basel, Switzerland. This article is an open access article distributed under the terms and conditions of the Creative Commons Attribution (CC BY) license (https:// creativecommons.org/licenses/by/ $4.0 /)$.

\begin{abstract}
The negative effects of urbanization such as urban overheating, pollution, high population density and so on are being experienced by city inhabitants more than ever, thus motivating a high number of researchers to find viable solutions to mitigate these effects. The present paper aims to identify an assortment of ornamental plants appropriate to be successfully used in various facade covering systems for buildings located in Eastern European countries. For this purpose, throughout a vegetation season, the project's team thoroughly monitored the percentage of survival, the coverage degree, and the behavior (biometric aspects and visual quality) of ten flowering species planted vertically and being oriented towards all four cardinal points. At the same time, the team conducted a thorough monitoring of some parameters of the soil ( $\mathrm{pH}$, humidity, and temperature) and of the outside environment (light intensity and temperature). Two experimental structures were built, insulated on the inside and covered at the top with thermal insulating panels, to simulate the same conditions of an insulated and unheated construction. The monitoring results showed that Heuchera $x$ hybrida 'Fire Alarm', Heuchera $x$ hybrida 'Marmalade' and Festuca galuca had a healthy appearance throughout the year, regardless of the cardinal orientation while providing a good coverage of the vertical surface.
\end{abstract}

Keywords: green facades; ornamental plants; urban environment; green building envelopes; vertical greening system

\section{Introduction}

A major problem faced by big cities today is the acute lack of green spaces, which entails a series of well-known negative effects such as the increase in noise levels, overheating, and air pollution, etc., and thus negatively influences-in the medium and long term-not only the urban environment aspect but also the health of city inhabitants. In recent years, in parallel with the territorial, often chaotic expansion of cities, there have been numerous transformations in terms of their structure, architecture, and urban design, often to the detriment of green areas [1]. Green areas have proven their effectiveness in improving the urban environment and, implicitly, in increasing the quality of life. Unfortunately, however, there is an acute shortage of spaces in cities that can be greened. As a result, attention was directed to other surfaces that can be greened such as roofs and facades of buildings. In order for a green facade system to be effective, it is important that it is covered with plant species appropriate to the climatic conditions specific to the area in which it is to be implemented. Improper choice of plants can lead to their inability to develop harmoniously or even to their death.

Since a horizontal expansion of green spaces is unlikely because of the shortage of empty land, which, at least theoretically, could serve this purpose, the only viable solution 
is the vertical development of gardens. Currently, the installation of green roofs and walls are two techniques serving both to improve habitats and possessing great potential to achieve reconciliation ecology in urban areas [2]. Over the past decades, several studies have been carried out that have successfully proven that green walls can improve the performance of buildings by contributing to the consolidation and restoration of the urban environment [3].

Plants act as a solar filter that reduces heat on the facade of a building, thus preventing the absorption of thermal radiation by the construction materials [4]. The vertical arrangement creates an external insulating layer that can improve the thermal insulation coefficient of the building, contributing to energy saving in the summer by reducing the need for air conditioning and by reducing heat loss in the winter [5]. The microclimate created at the facade level is characterized by slightly lower temperatures and a higher relative humidity, which means that the green screen acts as a wind barrier and confirms the evapotranspiration effect of the plants [6].

Plants and partially the substrate that is part of a green facade system possess a number of beneficial functions, such as increasing biodiversity and ecological value, mitigating the urban heat island effect, providing thermal and sound insulation, increasing indoor and outdoor comfort, and improving air quality and social and psychological well-being of city dwellers [7] which further leads to their better health [8]. The use of plants to mitigate the heat island effect of urbanized areas and improve the quality of the environment becomes a key design aspect in the development of modern buildings. Moreover, the widespread use of green facade systems could also present a real impact on transforming the urban landscape [9]. Plants used in green facade systems must be able to cope with extreme conditions such as severe temperature differences, high pollution, and possible lack of water [10]. This is why it is absolutely necessary that the plants proposed to be planted in these systems are tested in advance in the climatic conditions of the area where they are to be used.

Fan [11] and Leather [12] pointed out through their studies that psychological health is affected by living and working in cities due to stressful work environments. Urban work environments, along with work activities, contribute to stress and mental fatigue. Green walls offer aesthetic variations in an environment where people carry out their daily activities. Numerous studies have linked the presence of plants to improving human health and mental well-being [13].

Considering that the climate of Eastern Europe has a pronounced temperate continental character with excessive variations including frosty winters and temperatures dropping below $-18{ }^{\circ} \mathrm{C}$ and hot summers, and with temperatures above $35^{\circ} \mathrm{C}$, sometimes with long periods of drought, it is a real challenge finding ornamental species that can survive and thrive throughout the year in vertical planting systems.

\section{Materials and Methods}

\subsection{Location and Climatic Conditions}

The climate in the area of Iasi County is integrated in all the natural conditions specific to the Moldavian Plateau and has a pronounced temperate continental character with excessive shade. The characteristic of the north continental climate is represented by the presence of hot summers with temperatures higher than $35^{\circ} \mathrm{C}$ and frosty winters with temperatures falling below $-18{ }^{\circ} \mathrm{C}$. Moreover, the months of June-August sometimes register periods of drought.

Climatic data in the Iasi area in 2020 showed that the average temperature was between $0.5^{\circ} \mathrm{C}$ (January) and $23.4^{\circ} \mathrm{C}$ (August), with a maximum value of $33.9^{\circ} \mathrm{C}$ in July; the rainfall was in the range of $1.6 \mathrm{~mm}$ (April) and $130.5 \mathrm{~mm}$ (May); the average humidity recorded was between $42 \mathrm{~g}$ (April) and $91 \mathrm{~g}$ (December); and the wind intensity between 1.4 and $2 \mathrm{~m} / \mathrm{s}$ (January-December) (NMA). 
The experiment is located in the didactic field of the floriculture discipline, Faculty of Horticulture within the University of Life Sciences from Iași City, in north-eastern Romania (GPS decimal lat. N 47.1941, long. E 27.5555).

\subsection{Experience Design}

To serve the purpose of this experiment, two experimental structures (C1 and C2) were built; the base was square-shaped (each side equal to $2.60 \mathrm{~m}$ ) with a height of $2.40 \mathrm{~m}$ (Figure 1).

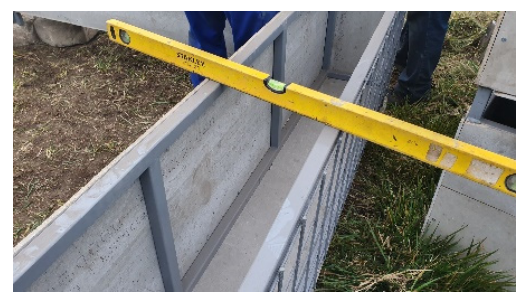

(a)

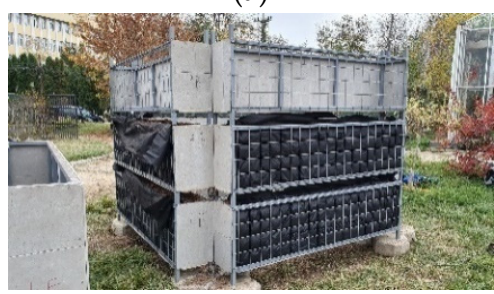

(c)

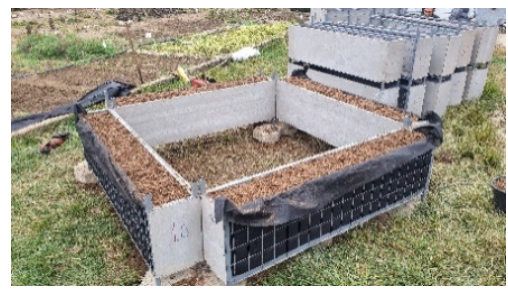

(b)

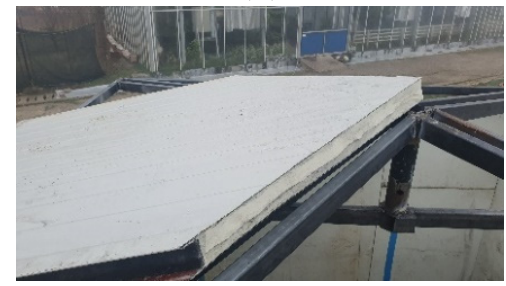

(d)

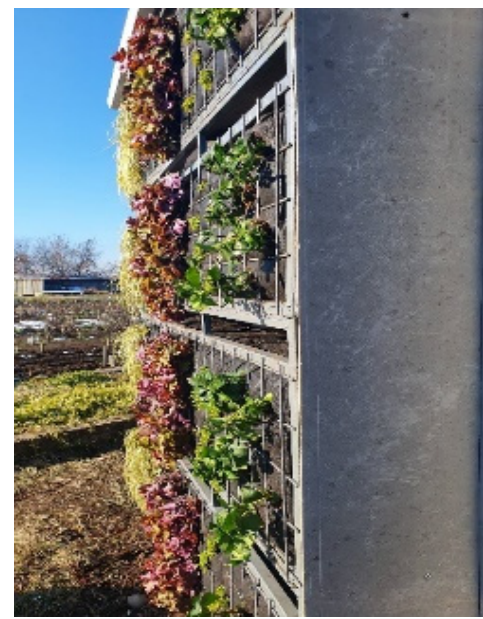

(e)

Figure 1. Realization of experimental structures: (a) flatness check 1 ; (b) fitting the first level of the experimental structure $\mathrm{C} 1$; (c) mounting the upper tiers; (d) insulation of the roof with heat-insulating panels; and (e) planted facade (south) of the experimental structure C2.

The structures were insulated on the inside and covered at the top with heat-insulating panels so as to simulate an insulated and unheated construction.

Each facade consists of 4 equal levels, $2 \mathrm{~m}$ long, $0.50 \mathrm{~m}$ height, and $0.3 \mathrm{~m}$ depth. The levels were plated with BETONYP on the sides, back, and bottom, and at the front they were closed with $10 \times 10 \mathrm{~cm}$ welded mesh to protect the substrate and the supporting foil (Geotex 50-Nortene geotextile) and, at the same time, to allow the planting of the flowering species. The levels were placed on top of each other at a distance of $0.10 \mathrm{~m}$ from each other to allow watering of the substrate. The experimental structures were positioned on the ground so that each face was oriented towards a cardinal point. BETONYP prefabricated slabs are concrete slabs reinforced with wood chips that have a uniformly layered structure starting from both sides formed by fine wood fragments to the coarser central layer. They are light and resistant to rain and frost. Moreover, insects and fungi do not attack them or affect their surface (they are resistant to disease and pests).

A total of ten flower species were chosen (Heuchera $x$ hybrida 'Fire Alarm', Festuca glauca, Sedum spurium 'Tricolor', Carex testacea, Polystichum aculeatum, Carex oshimensis 'Evergold', Sedum spurium 'Elisabeth', Heuchera $x$ hybrida 'Marmalade', Sedum acre 'Aurea', and Pachysandra terminalis) to be included in the study monitoring and evaluating their adaptability and behavior in vertical systems. The criteria underlying the choice of this first variety of plants took into account their permanence and decorative potential. Perennial species are hardy and require minimal maintenance. Flower species can provide decoration not only through flowers but also through their habitus, or the shape and color of the leaves. Therefore, the chosen species usually have a good resistance when grown in the field, require minimal maintenance and are decorative especially in shape and color of the leaves. They also have a not very deep root system that allows their cultivation in pots with limited substrate, thus being suitable for their cultivation in small spaces. There were 5 species planted per module, 26 plants of each species on all four facades of the 
experimental scheme. The species used in the experiment as well as their planting scheme are shown in Figure 2. The plants used were purchased as standard planting material and delivered in pots of appropriate size to each species.

(C1)

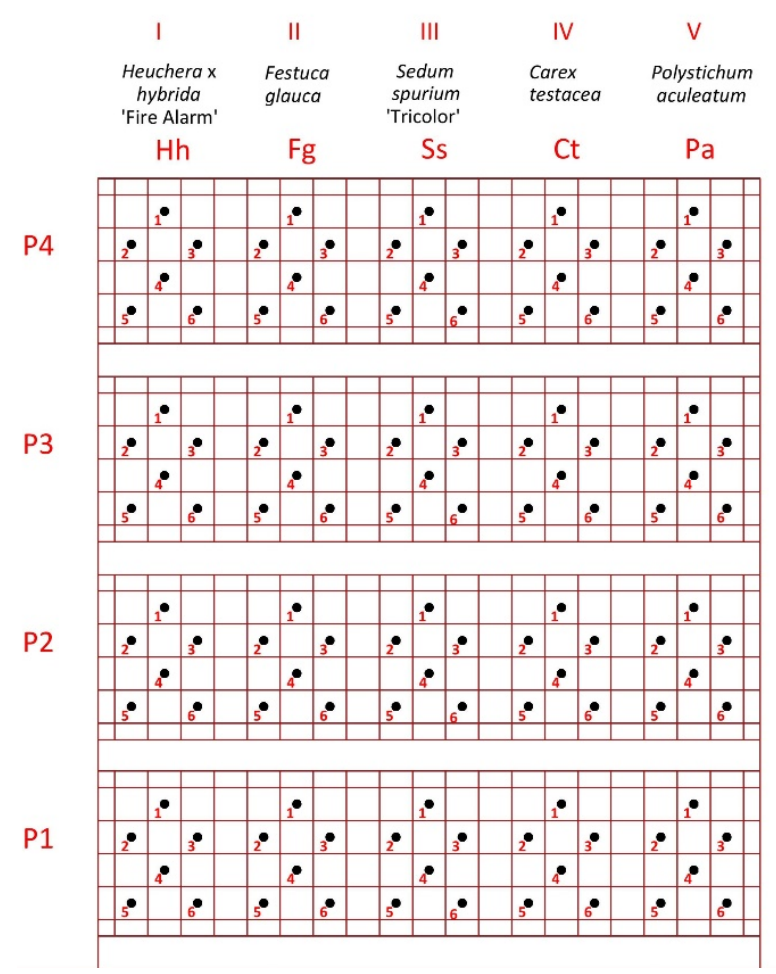

(a)

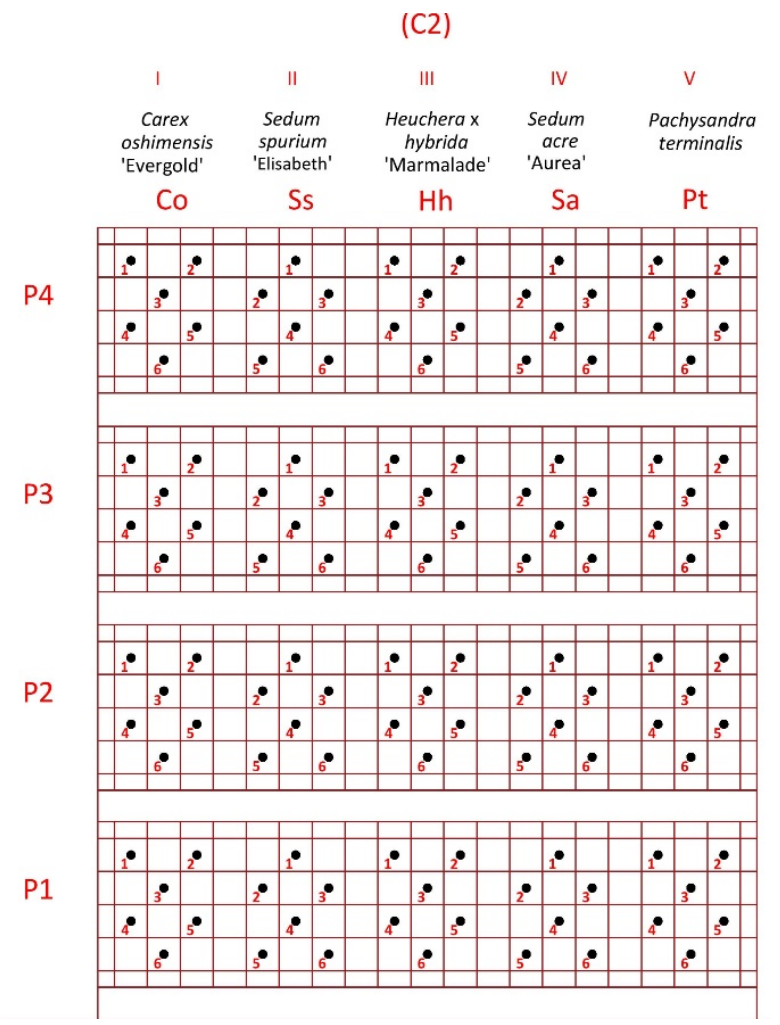

(b)

Figure 2. Planting plan of the flowering species; (a) species planted on the experimental structure C1; and (b) species planted on the experimental structure $\mathrm{C} 2$.

At the establishment of the experiment, all specimens of the same species were uniform in size and grown by the producer in identical pots, suitable for delivery as a material for the establishment of crops. The plants benefited from an adequate nutritional surface, on each facade of the experimental structure. At planting, the species had the following characteristics: Heuchera $x$ hybrida 'Fire Alarm': height $=17.3 \mathrm{~cm}$, diameter $=20.7 \mathrm{~cm}$, number of leaves $=82$; Festuca glauca: height $=21.3 \mathrm{~cm}$, diameter $=26.8 \mathrm{~cm}$; Sedum spurium 'Tricolor': height $=2.8 \mathrm{~cm}$, diameter $=8.4 \mathrm{~cm}$; Carex testacea : height $=18.9 \mathrm{~cm}$, diameter $=24.4 \mathrm{~cm}$; Polystichum aculeatum: height $=20.3 \mathrm{~cm}$, diameter $=26.1 \mathrm{~cm}$; Carex oshimensis 'Evergold': height $=32.2 \mathrm{~cm}$, diameter $=29.6 \mathrm{~cm}$; Sedum spurium 'Elisabeth': height $=3.9 \mathrm{~cm}$, diameter $=9.2 \mathrm{~cm}$; Heuchera $x$ hybrida 'Marmalade': height $=16.8 \mathrm{~cm}$, diameter $=36.4 \mathrm{~cm}$, number of leaves =114; Sedum acre 'Aurea': height $=6.2 \mathrm{~cm}$, diameter $=9.7 \mathrm{~cm}$, and Pachysandra terminalis: height $=11.6 \mathrm{~cm}$, diameter $=15.4 \mathrm{~cm}$.

The experiment was established in November 2019 (Figure 3), and the paper presents the observations/research conducted during year 2020. Watering was done manually and moderately in equal quantities and measured on each level.

The chosen substrate has a $\mathrm{pH}$ value equal to 6 and contains a mixture of white peat $(0-25 \mathrm{~mm})$, white peat bricks $(15-45 \mathrm{~mm})$ and $(25-45 \mathrm{~mm})$, white peat fibers, and clay content of $20 \mathrm{~kg} / \mathrm{m}^{3}$. The substrate used is a universal substrate valid for flower species grown in pots/planters for the outdoors. The $\mathrm{pH}$ value $=6$ was indicated by the manufacturer for the universal substrate used. 


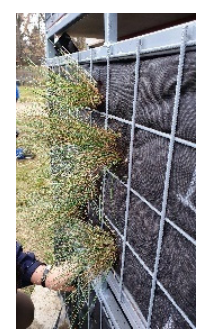

(a)

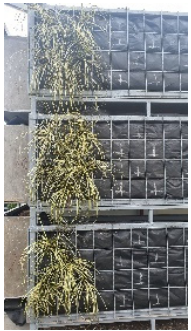

(c)

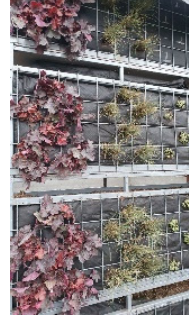

(b)

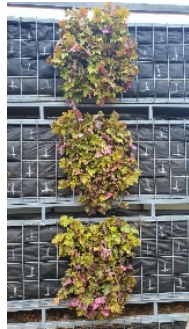

(d)

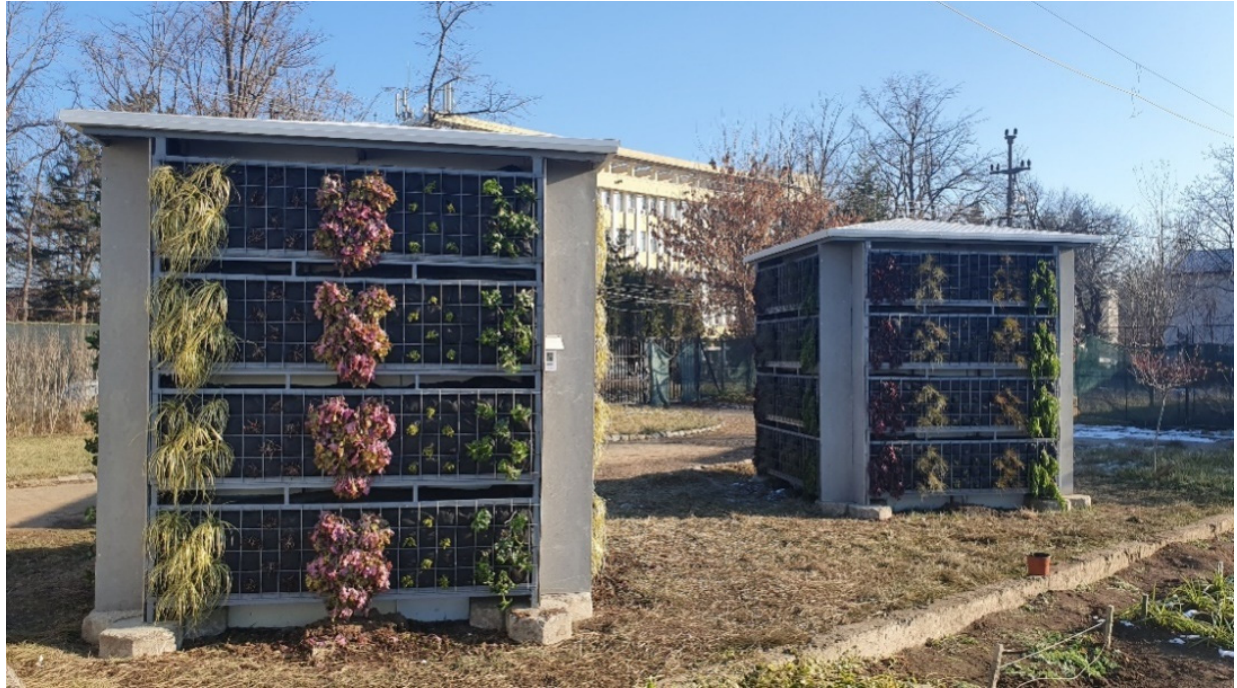

(e)

Figure 3. Planting floral species, 1st year: (a) Festuca glauca-C1; (b) Heuchera $x$ hybrida 'Fire Alarm', Festuca glauca and Sedum spurium 'Tricolor'-C1; (c) planting Carex oshimensis 'Evergold'-C2; (d) Heuchera $x$ hybrida 'Marmalade' - C2; and (e) experimental structures C1 and C2 after plantingwest side/orientation.

According to the literature, in general, most perennial floral species prefer slightly acidic soils/substrates ( $\mathrm{pH}$ 6-6.5) [14]. All species used in our study are suitable for slightly acidic substrate [15].

During the course of the experiment, the plants were monitored for the influence of environmental factors and the effect of the substrate on the plants' behavior.

Thus, the following were thoroughly monitored: the temperatures outside and inside the experimental schemes, the light intensity, the $\mathrm{pH}$, and the humidity and temperature of the substrate in which the flowering species were planted.

During the period in which the vertical behavior of the flower species was monitored, several parameters of the substrate in which they were planted were monitored. The temperatures recorded both inside and outside the experimental schemes were also noted. The collection of these data was done in the same time interval 12:00 p.m.-2:00 p.m.

The temperature values measured inside the experimental structures were between $-1.7^{\circ} \mathrm{C}$ in December and $32.7^{\circ} \mathrm{C}$ in August, and outside the structures between $-1.9^{\circ} \mathrm{C}$ in February and $26.9^{\circ} \mathrm{C}$ in August.

The monitoring was conducted using two different devices, every three days, within the same time interval, on each level.

The device measuring the external and internal temperatures is fixed, mounted at the same height and orientation (west facade) on each experimental unit (Figure 4a). The outside and inside temperatures of the experimental schemes were measured with a Somogyi Elektronic Home HC 12 device with a resolution of $0.1^{\circ} \mathrm{C}$. The indoor sensor was mounted in the middle of the experimental structure at $1.50 \mathrm{~m}$ from the ground. The other recordings were made with mobile monitoring devices (Figure $4 \mathrm{~b}$ ), their use being illustrated in Figure 4c. The other parameters were monitored using a soil hygrometer for plants: RZ89 4 IN 1 3.5 9 PH Meter Digital Magnetic Soil Health Analyzer Machine Soil Moisture-Monitor Hygrometer Gardening Plant Tester. The storage of these data was done with the help of applications in the cloud [16]. 


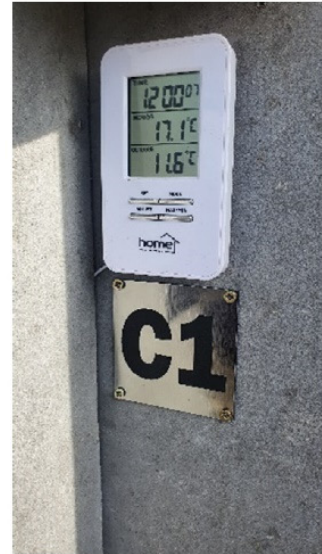

(a)

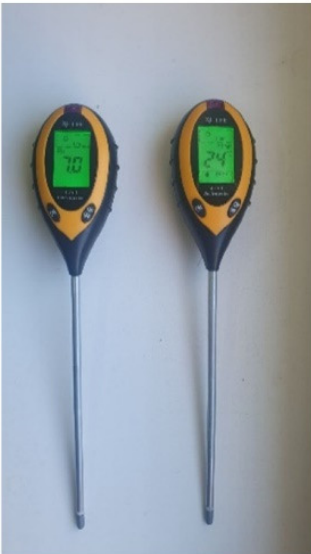

(b)

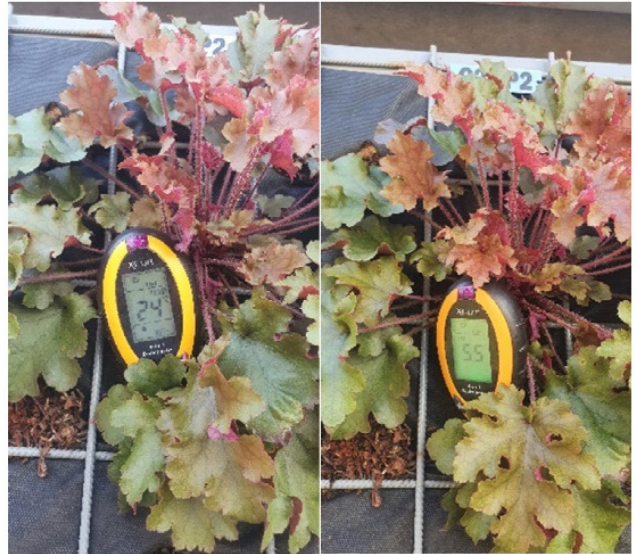

(c)

Figure 4. Devices used to monitor the parameters of the soil ( $\mathrm{pH}$, humidity, and temperature) and of the outside environment (light intensity and temperature). (a) Fixed devices used to measure indoor and outdoor temperature; (b) mobile device for measuring luminous intensity, $\mathrm{pH}$, temperature, and humidity; and (c) method of measuring the monitored parameters using the mobile device.

At the same time, the behavior of each species (coefficient of survival, degree of coverage, general appearance, etc.) was monitored for each orientation separately. In this regard, three data sets were collected, two of them during the growing season (May and August) and one during the rest period (December); furthermore, depending on each species planted, certain characteristics were recorded, such as: the height of the plant, the diameter of the plant, the number of leaves, the number of inflorescences, and the length of the floriferous stems and the inflorescence. two-factor ANOVA was used for statistical interpretation of the data. The definitions of the parameters used are as follows: wall coverage $=$ percentage value of the area covered by a species (\% percent); survival coefficient $=$ what percentage of the total number of plants in a species have withstood the temperature conditions over the winter and during the vegetation period (\% percent); plant height $=$ measured distance perpendicular to the facade, from the level of the facade to the extremity of the plant $(\mathrm{cm})$; and plant diameter = measured distance between the extremities of the plant, parallel to the facade, horizontally $(\mathrm{cm})$.

\section{Results}

The flowering species were regularly monitored (visually and photographically), along with the registration of temperatures with the aforementioned devices, to capture every aspect of how the plants evolved. The observations made are summarized below.

At the end of the cold season (Spring 2020) a first survival coefficient was calculated, obtaining the following values: Heuchera $x$ hybrida 'Fire Alarm' $(26.04 \%)$, Festuca glauca (91.66\%), Sedum spurium 'Tricolor' (90.62\%), Carex testacea (5.20\%), Polystichum aculeatum (27.20\%), Carex oshimensis 'Evergold' (13.54\%), Sedum spurium 'Elisabeth' (69.79\%), Heuchera $x$ hybrida 'Marmalade' (20.83\%), Sedum acre 'Aurea' (91.66\%), and Pachysandra terminalis (50\%).

The two species of Sedum spurium had a favorable evolution at the beginning of the growing season, but along the way, they suffered severe attacks of powdery mildew that significantly affected the appearance of the plants.

Sedum spurium 'Tricolor' recorded a total survival percentage of $90.62 \%$, with a survival percentage of $100 \%$ on two of the orientation patterns (north and west). It entered the vegetation stage early, at the beginning of March, and developed rapidly, providing, in early May, a high degree of coverage, especially on the western side where the wall coverage was $70.83 \%$.

Flowering occurred in early May—first on the south face and then on the west and east ones. 
Plant development was halted by the first powdery mildew attack that took place in the first period of May and affected first the Sedum spurium 'Tricolor' plants on the eastern facade (Figure 5), and then those on the southern one. By early June, specimens planted on the north and west facades were also affected. The second attack began at the end of August-first on the northern facade and then on the eastern facade.

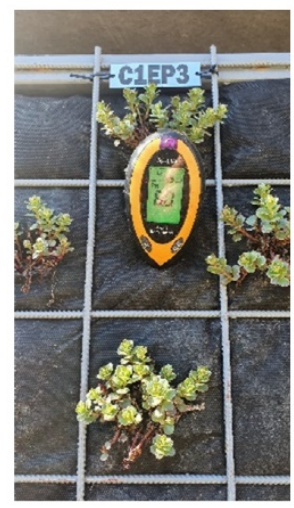

(a)

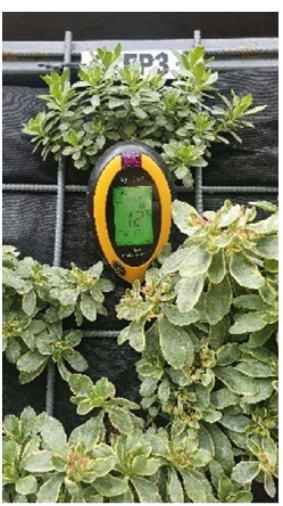

(b)

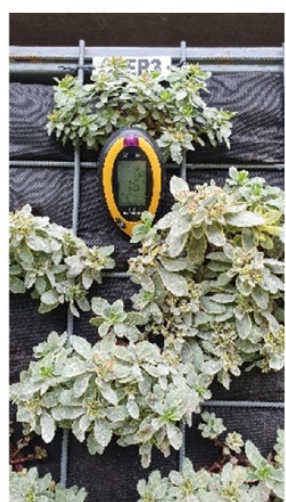

(c)

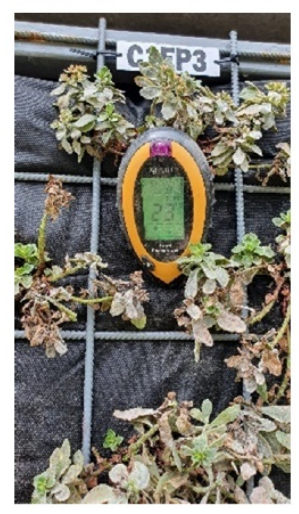

(d)

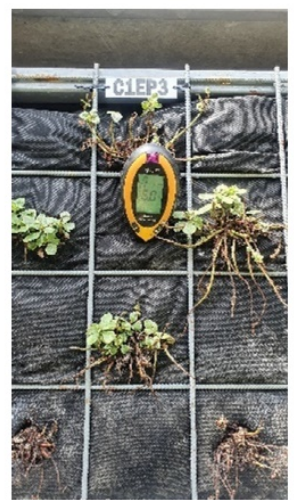

(e)

Figure 5. Evolution Sedum spurium 'Tricolor' March-June 2020 level 2, eastern facade: (a) 12 March 2020; (b) 8 May 2020; (c) 17 May 2020; (d) 7 June 2020; and (e) 16 June 2020.

In the case of Sedum spurium 'Elisabeth', the powdery mildew attack occurred in the first decade of June, mainly on the north side where the severity of the attack led to the loss of plants. On the other facades, the attack was of low intensity allowing the plants to develop and even bloom especially on the western facade. Figure 6 shows images that capture the appearance of the Sedum spurium 'Elisabeth', on the same date, on the second floor on each of the four facades.

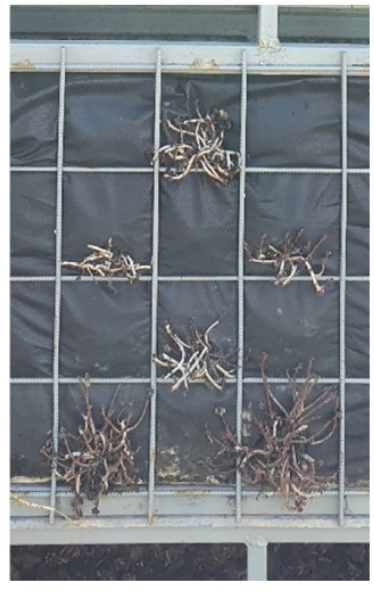

(a)

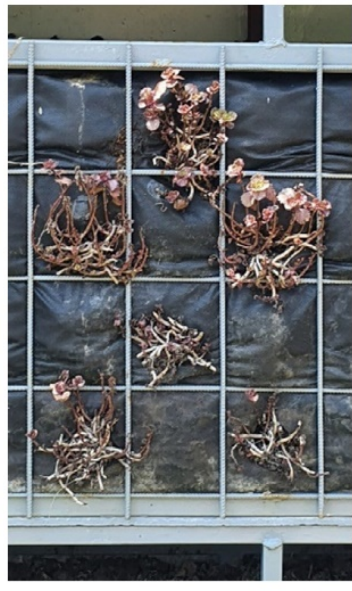

(b)

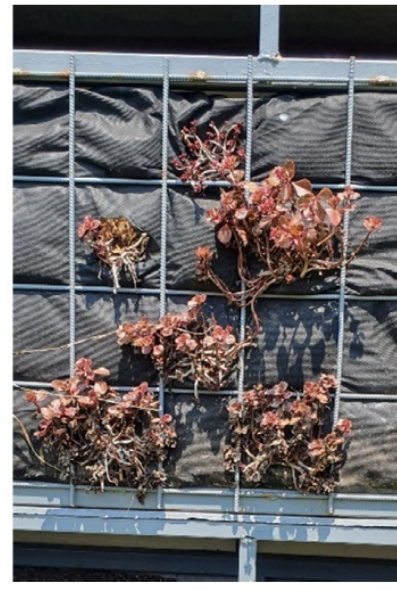

(c)

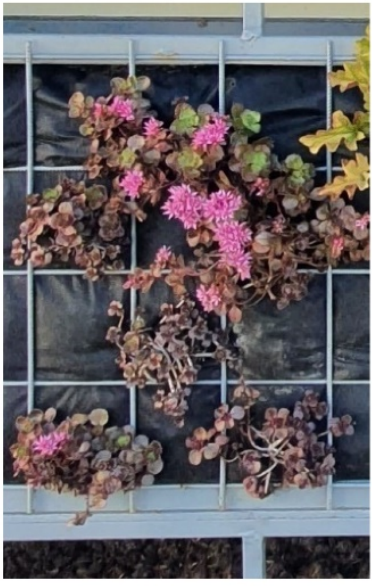

(d)

Figure 6. Sedum spurium 'Elisabeth'-level 2, July 2020 (8 July 2020): (a) north; (b) east; (c) south; and (d) West.

Moreover, in the first part of the growing season, a good development was registered in the case of the species Sedum acre, but their increase in volume could not be supported by their extremely frail root system, so that most of them, coming out of the substrate under their own weight, began to dry out (Figure 7). 


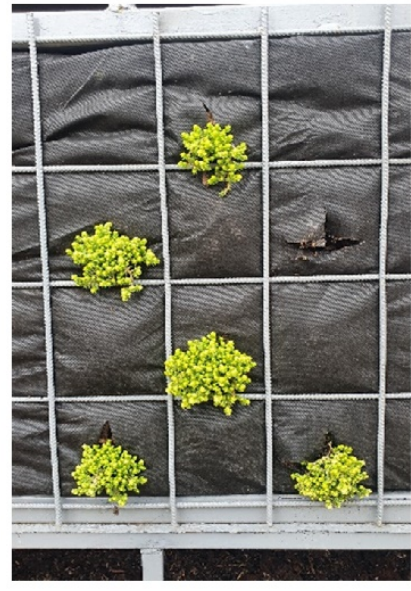

(a)

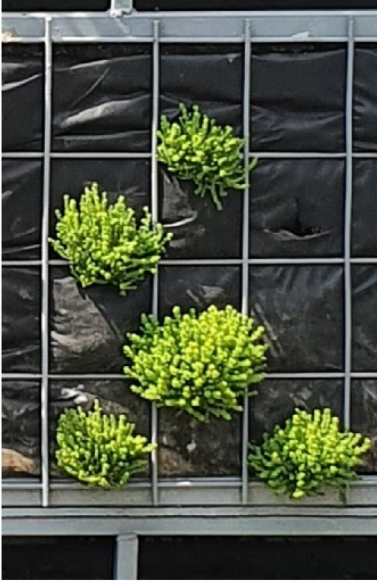

(b)

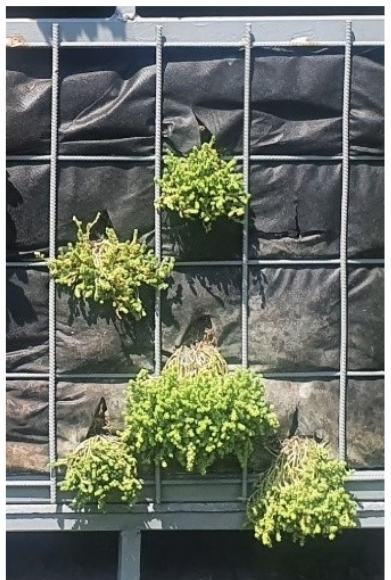

(c)

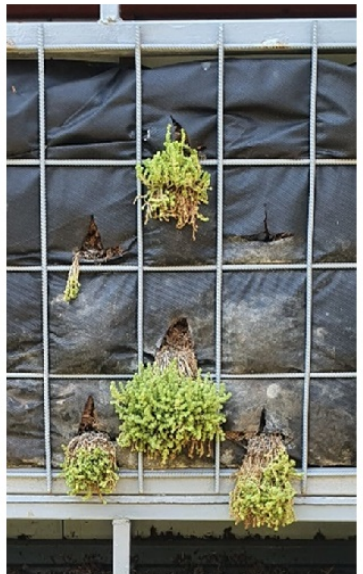

(d)

Figure 7. Evolution of Sedum acre March-July 2020, level 2 eastern facade: (a) 3 March 2020; (b) 2 May 2020; (c) 19 June 2020; and (d) 4 July 2020.

A good start was also registered in the case of the species Pachysandra terminalis, but the climatic factors of the summer period have seriously affected the specimens of this species on all the facades of the experimental scheme (Figure 8). In this context, at the end of August, the survival percentage dropped to $30.20 \%$.

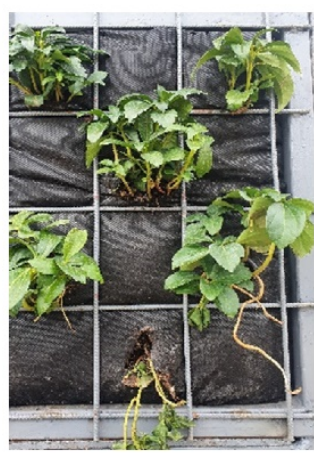

(a)

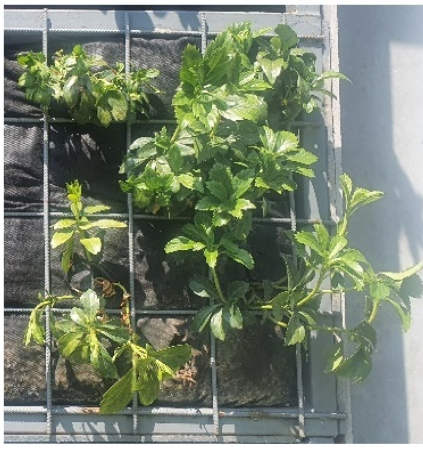

(b)

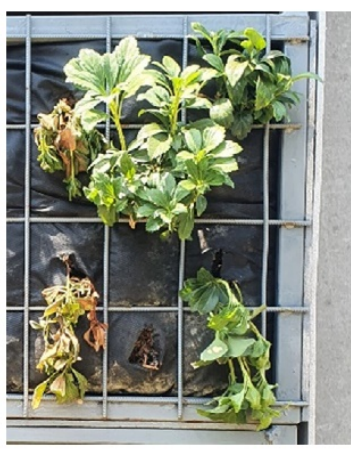

(c)

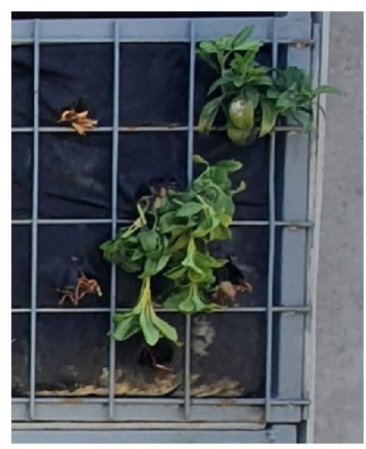

(d)

Figure 8. Pachysandra terminalis March-August 2020, level 3 eastern facade: (a) 3 March 2020; (b) 19 June 2020; (c) 4 July 2020; and (d) 3 August 2020.

Polystichum aculeatum had a difficult start and a modest evolution during the monitoring period on all the facades of the experimental module.

For example, Figure 9 presents stages of development of this species, on the first level, on all the facades of the experimental scheme $\mathrm{C} 1$.

Festuca glauca, in addition to the very good survival percentage, also demonstrated good evolution and a high degree of coverage on all the facades of the experimental structure except for the southern facade where the highest percentage of specimens lost during the growing season was recorded (Figure 10). Thus, if at the beginning of the season on the southern part there was a survival percentage of $87.6 \%$, by the end of the year (December 2020) it decreased to $54.16 \%$. The entire module recorded a $30.36 \%$ decrease in the survival percentage, reaching $61.90 \%$ at the end of the year. 


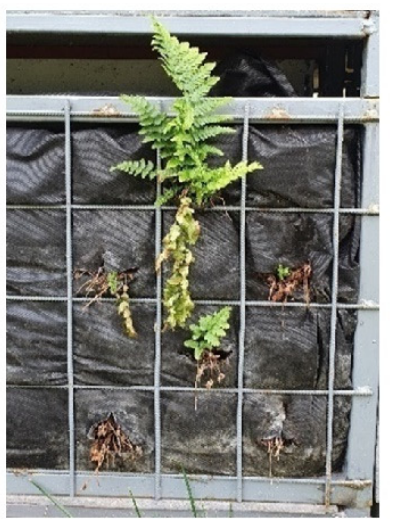

(a)

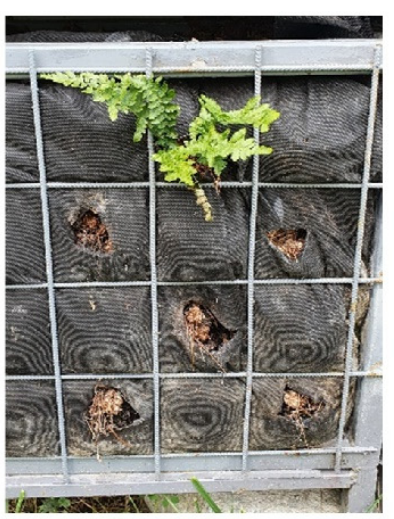

(b)

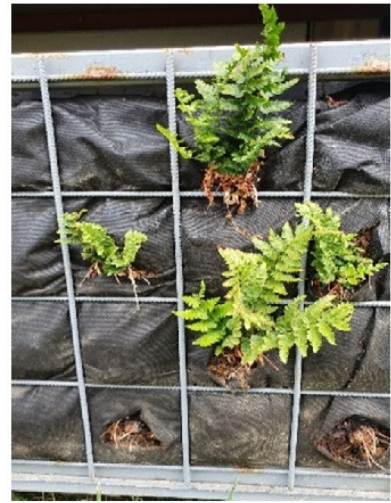

(c)

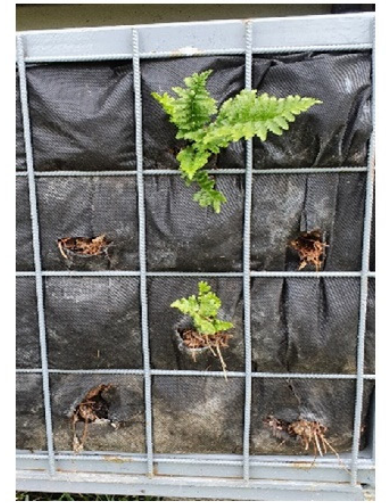

(d)

Figure 9. Polystichum aculeatum-level 1 July 2020 (13 July 2020): (a) north; (b) east; (c) south; and (d) west.

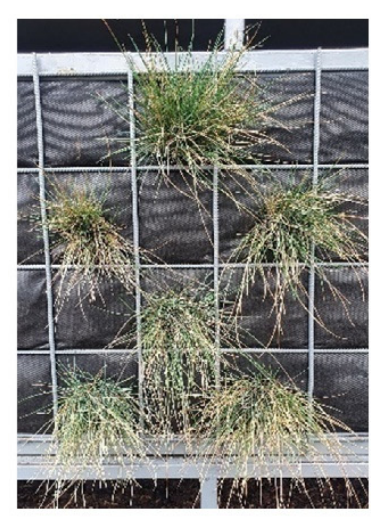

(a)

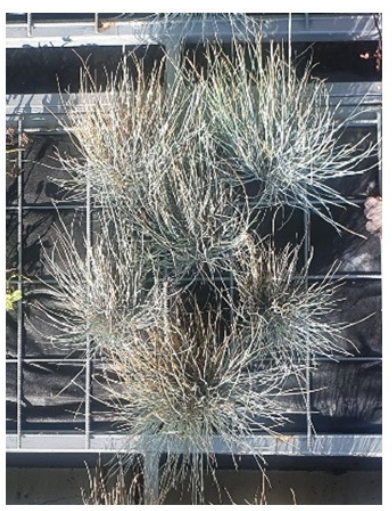

(b)

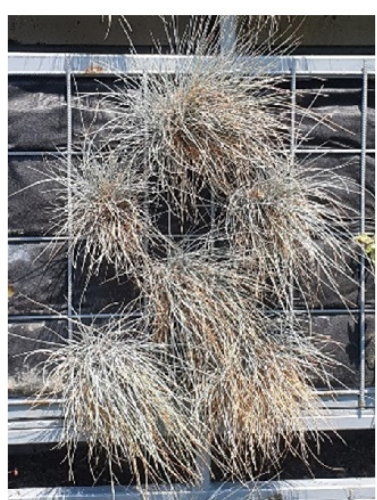

(c)

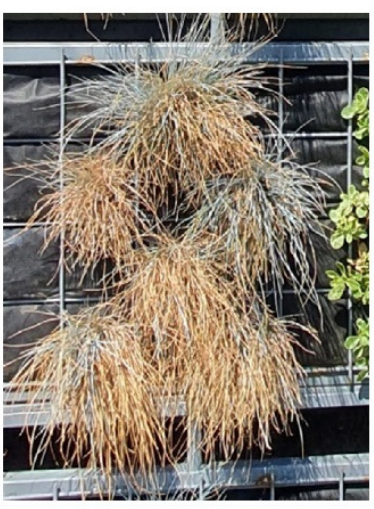

(d)

Figure 10. Festuca glauca March-August 2020, level 2 southern facade: (a) 3 March 2020; (b) 19 June 2020; (c) 4 July 2020; and (d) 3 August 2020.

Although they recorded a survival percentage below 30\%, the two varieties of Heuchera $x$ hybrida demonstrated a very good evolution. The remaining specimens developed harmoniously, presenting a healthy appearance throughout the year. The losses during the growing season were about $5 \%$ in both varieties.

In the case of these last three species, three sets of biometric measurements were also carried out: two during the vegetation period (May and August) and one during the vegetative rest period (December).

Festuca glauca demonstrated, in a short time, a good adaptability and a high degree of coverage of the vertical surface. The exception was the specimens on the southern facade where, as mentioned earlier, the results were worse. The plants that remained in the experiment provided decor throughout the year (Figure 11). 


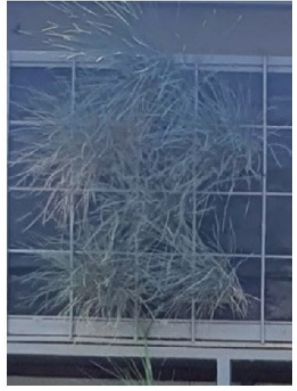

(a)

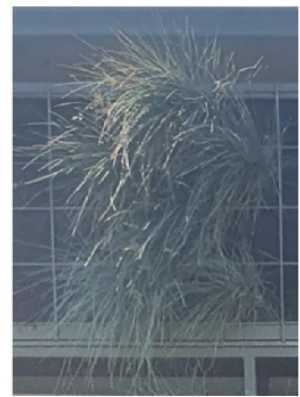

(b)

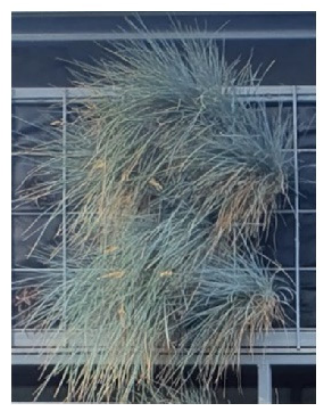

(c)

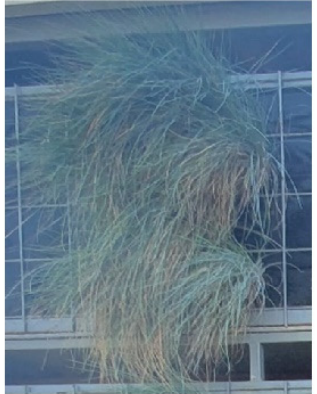

(d)

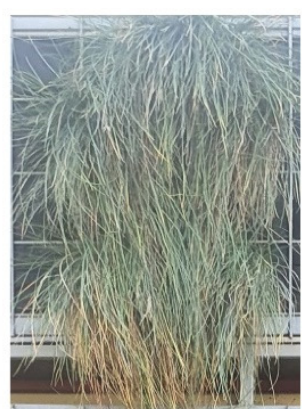

(e)

Figure 11. Festuca glauca May-December 2020, level 4 northern facade: (a) May; (b) June; (c) July; (d) October; and (e) December.

Following the analysis of the collected data, it is found that the Festuca glauca plants demonstrated the best development on the north-facing facade, where both their height and their diameter recorded the highest average values in all three sets of measurements made. The exception is May, where the diameter of the plants on the eastern facade was slightly larger (by $0.63 \%$ ) than that of the northern facade. At the opposite pole, the lowest average values in the case of these two parameters were recorded on the south-facing facade. On the east and west facing facades, these characteristics obtained close average values (Figure 12).

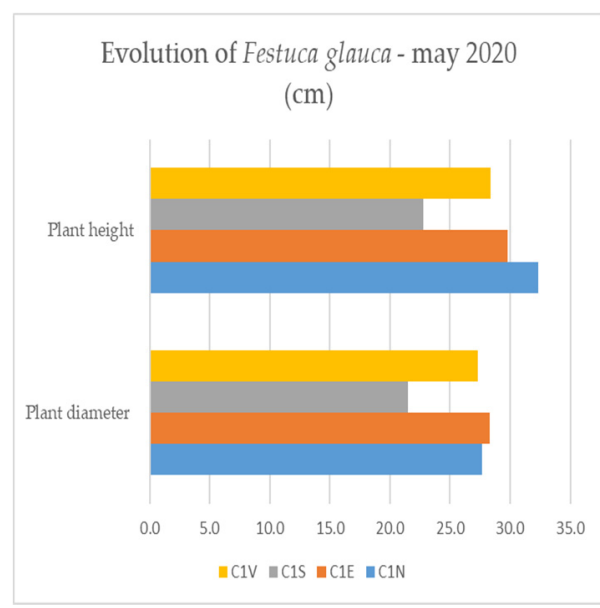

(a)

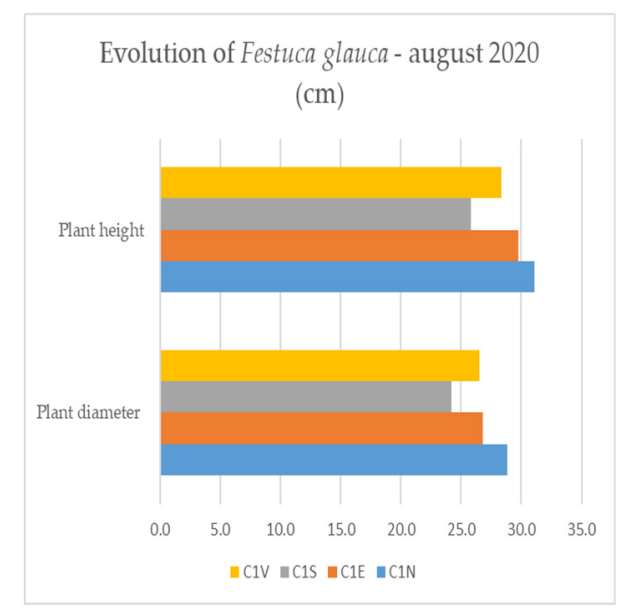

(b)

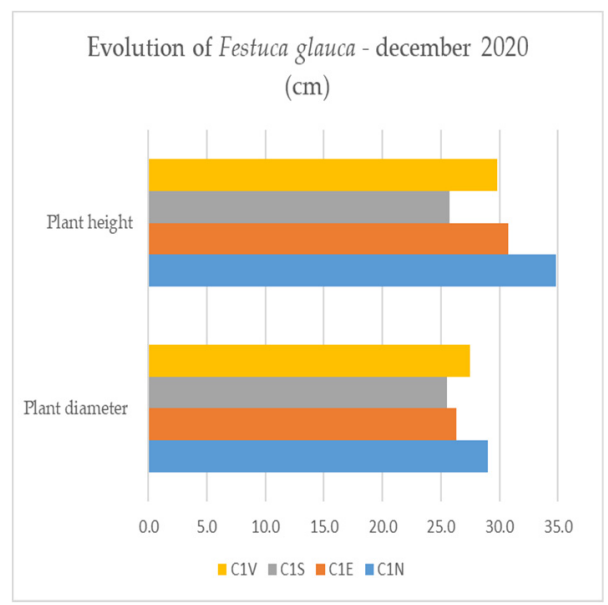

(c)

Figure 12. Evolution of height and diameter at Festuca glauca, May-December 2020 on cardinal orientations: (a) May; (b) August; and (c) December. 
As for the flowering, the largest average number of inflorescences per plant was obtained on the western facade followed closely by the one obtained on the eastern facade. The fewest floriferous stems were developed by the specimens planted on the southern facade. The cardinal orientation had the same influence on the lengths of the floriferous stems and their inflorescences, with the highest average values being obtained on the western facade (Table 1).

Table 1. Blossoming Festuca glauca.

\begin{tabular}{cccc}
\hline $\begin{array}{c}\text { Cardinal Orientation of } \\
\text { the Facade, Experimental } \\
\text { Scheme }\end{array}$ & $\begin{array}{c}\text { Number of Flower } \\
\text { Stems }\end{array}$ & $\begin{array}{c}\text { Total Length of } \\
\text { Flower Stem } \\
\mathbf{( c m )}\end{array}$ & $\begin{array}{c}\text { Length of } \\
\text { Inflorescence } \\
\text { (cm) }\end{array}$ \\
\hline C1N & 2.83 & 17.71 & 5.01 \\
C1E & 4.20 & 19.18 & 6.32 \\
C1S & 1.00 & 9.00 & 4.00 \\
C1W & 5.00 & 19.21 & 5.31 \\
\hline
\end{tabular}

Heuchera $x$ hybrida 'Marmalade' distinguished itself by its healthy and rich foliage and its healthy and resistant appearance throughout the growing season, regardless of the cardinal orientation. Figure 13 captures the evolution of this plant on the eastern facade of the experimental scheme.

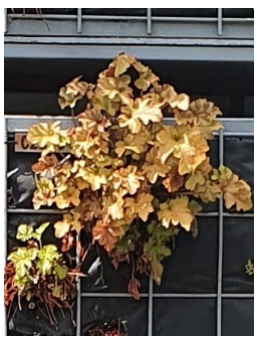

(a)

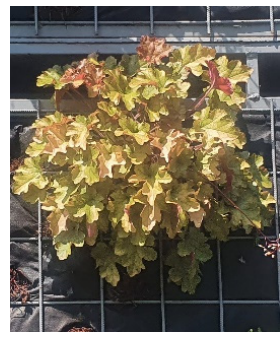

(b)

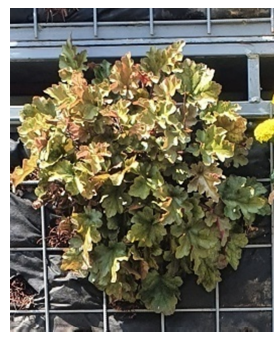

(c)

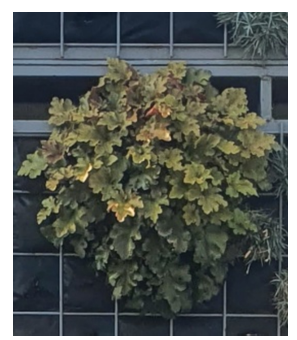

(d)

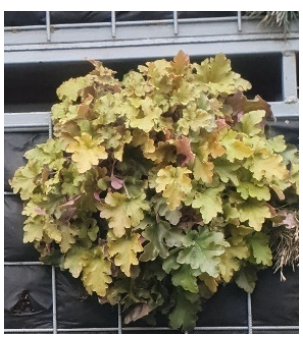

(e)

Figure 13. Heuchera $x$ hybrida 'Marmalade' May-December 2020, level 3, eastern facade. (a) May; (b) June; (c) August; (d) October; and (e) December.

As for the diameter and height of the plant, the eastern orientation was the most favorable. The lowest average values were recorded for these two parameters on the southern facade in May and December and on the western facade in August (Figure 14).

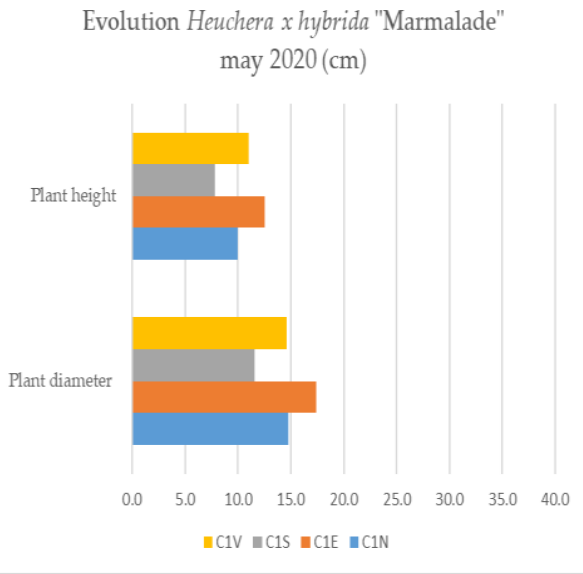

(a)

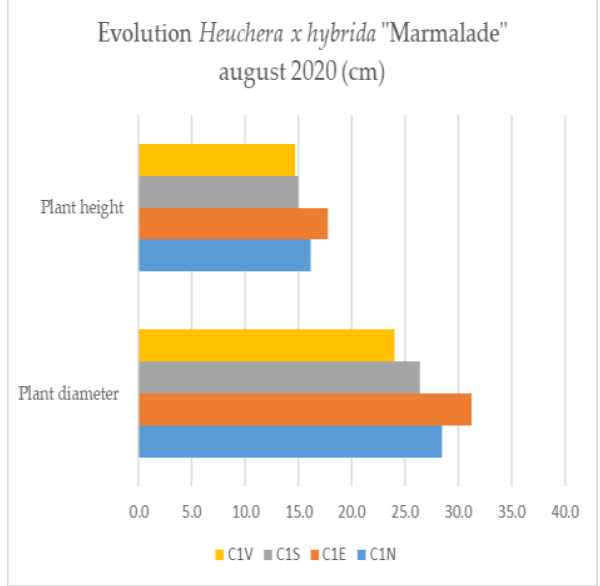

(b)

Figure 14. Cont. 


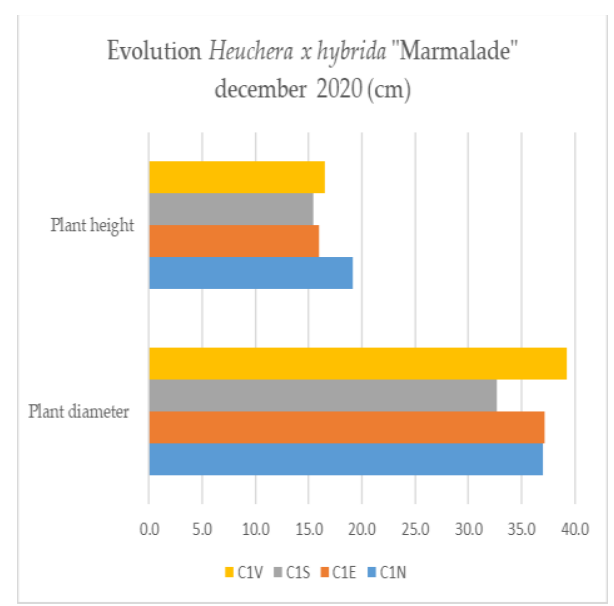

(c)

Figure 14. The evolution of height and diameter Heuchera $x$ hybrida 'Marmalade', May-December 2020 on cardinal orientations: (a) May; (b) August; and (c) December.

The highest average values, in terms of the number of leaves, was obtained on the eastern facade in May, August, and December (Figure 15).

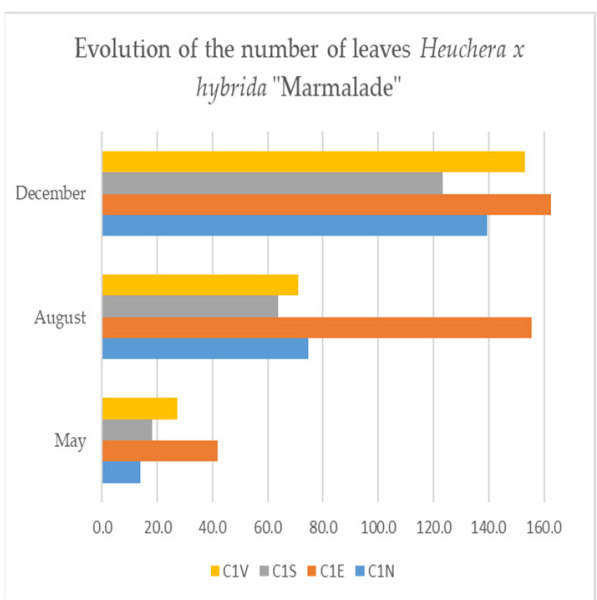

Figure 15. Evolution of the number of leaves in Heuchera x hybrida 'Marmalade', May-December 2020.

Flowering in this hybrid was poor, both in number of floriferous stems and in terms of duration of flowering, but the decorative appearance was provided by a significant number of leaves. Moreover, the eastern orientation favored flowering so that on the eastern facade there was recorded an average of 5.5 inflorescences per plant and an average length of the floriferous stems of $35.5 \mathrm{~cm}$. On the northern face, no plants bloomed.

Moreover, Heuchera $x$ hybrida 'Fire Alarm' distinguished itself by its healthy foliage, abundant flowering, and especially by its resistance in this system throughout the year, on all four facades (Figure 16). 


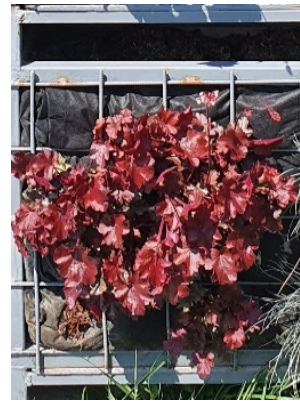

(a)

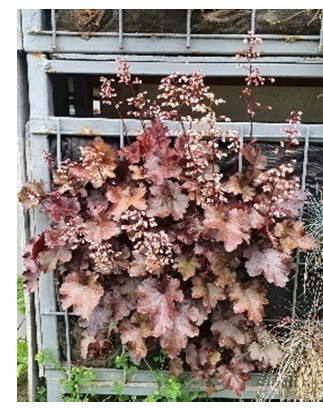

(b)

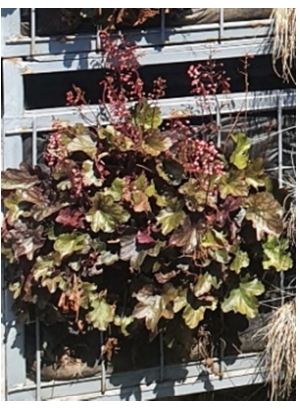

(c)

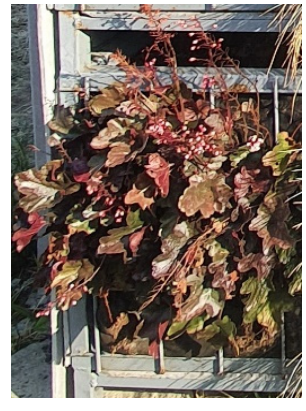

(d)

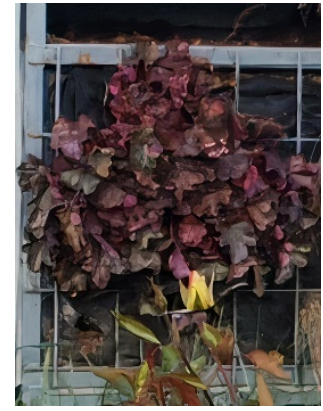

(e)

Figure 16. Heuchera $x$ hybrida 'Fire Alarm' May-December 2020, level 1, southern facade: (a) May; (b) June; (c) August; (d) September; and (e) December.

As for the height and diameter of the plant, in the growing season (May and August) on the southern and western facades, the highest average values were recorded. During the rest period, on these facades, the mentioned parameters recorded the lowest average values but were closest to the values obtained on the other cardinal orientations (Figure 17).

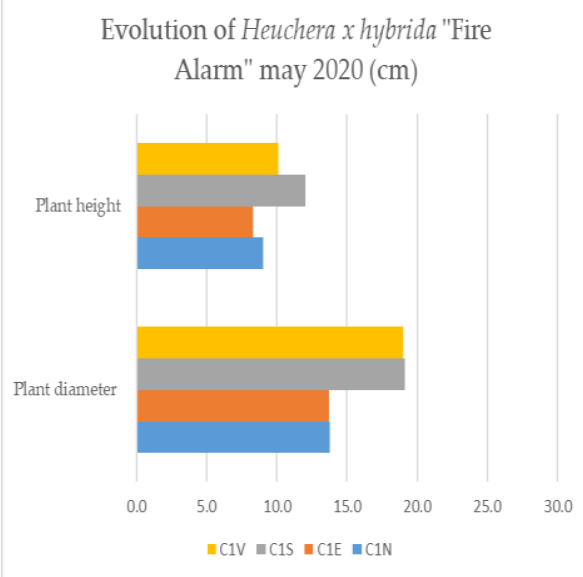

(a)

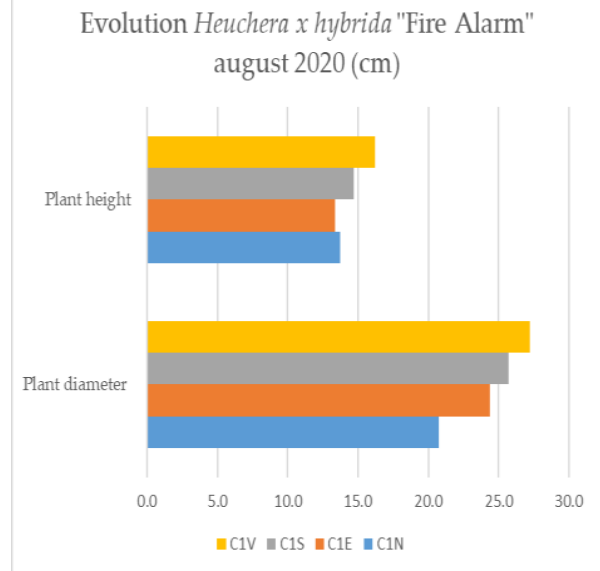

(b)

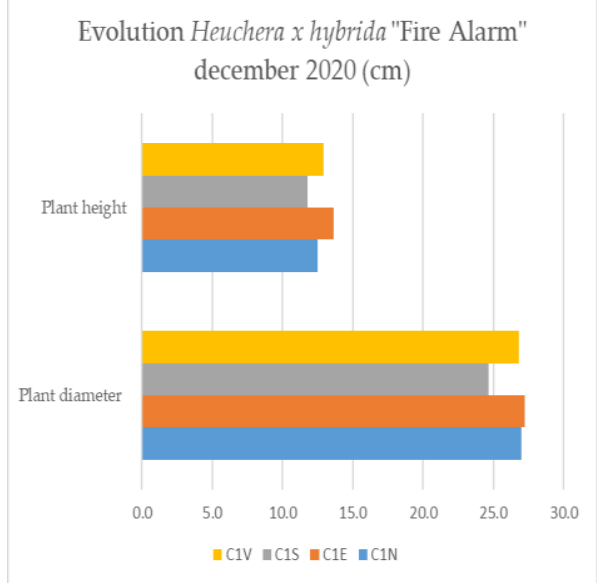

(c)

Figure 17. Evolution of height and diameter at Heuchera $x$ hybrida 'Fire Alarm', May-December 2020 on cardinal orientations: (a) May; (b) August; and (c) December.

The number of leaves in May reached the highest value on the southern facade. In August and December the highest average value was noted on the western facade 
(Figure 18). In all three sets of measurements, the lowest average value was recorded on the northern facade for this parameter.

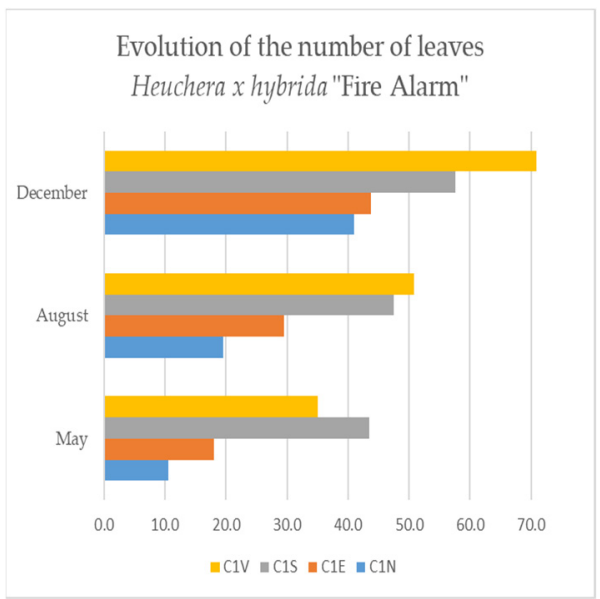

Figure 18. Evolution of the number of leaves in Heuchera $x$ hybrida 'Fire Alarm', May-December 2020.

The southern orientation favored flowering, which started in May on the mentioned orientation, followed by the eastern and western orientations and then on the northern facade. On the southern and western facades, the duration of flowering was the longest, respectively, until mid-November. The number of floriferous stems was higher on the southern facade, but the lengths of the floriferous stems as well as the inflorescences had the lowest average values. The highest average values for these parameters were recorded on the eastern facade closely followed by those obtained on the western facade (Table 2).

Table 2. Flowering Heuchera x hybrida 'Fire Alarm' 2020.

\begin{tabular}{cccc}
\hline $\begin{array}{c}\text { Cardinal Orientation } \\
\text { of the Facade } \\
\text { Experimental } \\
\text { Scheme }\end{array}$ & $\begin{array}{c}\text { Number of } \\
\text { Floriferous Rods }\end{array}$ & $\begin{array}{c}\text { Total Length of } \\
\text { Floriferous Rods } \\
\text { (cm) }\end{array}$ & $\begin{array}{c}\text { Length of } \\
\text { Inflorescence } \\
\text { (cm) }\end{array}$ \\
\hline C1N & 4 & 19.68 & 7.055 \\
C1E & 6.66 & 20.98 & 7.50 \\
C1S & 7 & 16.98 & 6.07 \\
C1W & 6.4 & 19.80 & 6.728 \\
\hline
\end{tabular}

\section{Discussion}

A green facade reaches its maximum potential when the plants that compose it have a compact, healthy appearance and develop properly. The general appearance of plants (shape, arrangement of the component parts, etc.) influences surface temperatures [17]. Thus, it was found that a higher density of foliage produces a localized cooling that leads to a lower temperature at the level of the facade [8]. In this regard, it has been proven that plants have different performances [18]. In an experiment conducted in the Scandinavian climate, several plant species were tested. A harmonious development and good quality of coverage were observed in the following species: Achillea millefolia, Bergenia cordifolia, Dianthus deltoides, Molinia caerulea, Nepeta faassenii, Salvia nemorosa, Sesleria heuffleriana, Antennaria dioica, Armeria maritima, Iberis sempervirens, and Pilosella aurantiaca. These species showed a lower degree of coverage, but their healthy and compact appearance recommend them to be used in combination with species with better coverage [10].

In the current experiment, the best survival coefficient of $91.66 \%$ was recorded in the species Festuca glauca and Sedum acre 'Aurea'. At the opposite pole are the two species of Carex that recorded values of $5.20 \%$ (Carex testacea) and $13.54 \%$ (Carex oshimensis). The very low survival percentages obtained by the Carex species led to the abandonment of their 
monitoring in the presented system. Sedum species had high survival percentages (between $69.79 \%$ and $91.66 \%$ ) and a good start at the beginning of the growing season, but their subsequent evolution was unfavorable, which is why they were no longer of interest in the study of plant behavior in this system. With an initial grip of 50\%, Pachysandra terminalis also had a good start but over the summer the plants began to suffer and dry out. During this period, $39.60 \%$ of all plants that survived over the winter were lost. Consequently, this species was removed from the study. The small percentage of survival, the modest onset, and the general appearance of plants of Polystichum aculeatum also eliminated this species from the experiment.

In terms of visual quality and coverage, Festuca glauca, Heuchera $x$ hybrida 'Fire Alarm' and Heuchera $x$ hybrida 'Marmalade' were favorably noticed. Festuca glauca demonstrated a favorable development ensuring decoration throughout the year on the whole experimental scheme. However, on the southern facade, the development of Festuca glauca plants was more modest, registering the majority of losses during the year on this part. During the entire monitoring period, the hybrids of Heuchera had a compact appearance, rich and healthy foliage, and easily covered the surface of the vertical system. The losses during the growing season were small compared with the other species studied.

For the dataset collected from Heuchera $x$ hybrida 'Fire Alarm', their statistical analysis was carried out using the two-factor ANOVA. Thus, in terms of plant diameter, the calendar month significantly influences the diameter of the plant ( $p$ value $<0.05$ ), though there is no significant difference between the average values of the diameter on the northern facades of the experimental units ( $p$ value $>0.05$ ), that is, the cardinal orientation did not influence this parameter.

Similarly, statistically analyzed data for the height of the plant were interpreted. This parameter is significantly influenced only by the calendar month in which the data were collected ( $p$ value $<0.05)$ and not by the cardinal orientation $(p$ value $>0.05)$.

There is also no interaction between the calendar month in which the data were collected and the cardinal orientation $(p$ value $>0.05)$ for both analyzed parameters. The number of leaves was significantly different from one month to another and, within the same set of measurements, from one orientation to another ( $p$ value $<0.05$ ). Instead, the interaction between the month when data was collected and the cardinal orientation ( $p$ value $>0.05$ ) does not determine significantly different values (Analysis ToolPak in MS Excel 2016).

The results obtained during the experiment motivate the continuation of the study of plant behavior by resorting to another planting age and subsequently to other types of substrate, in order to improve the coefficient of attachment. Furthermore, a parallel monitoring of the way the flowering species develop on the ground will be conducted in a control group. Moreover, other perennial flowering species will be introduced in the study to expand the assortment of plants that can be used in various systems for green facades on buildings located in the area where the research is carried out.

\section{Conclusions}

Following the observations made, it was found that in the climatic conditions in northeastern Romania, the following species had a good suitability in the green facade culture system: Heuchera $x$ hybrida 'Fire Alarm', Heuchera $x$ hybrida 'Marmalade', and Festuca galuca will be maintained in the study. They performed favorably in terms of their rich foliage and healthy appearance throughout the year regardless of the cardinal orientation. They also had a good capacity to cover the facade. Furthermore, Festuca galuca additionally recorded a survival percentage of over $90 \%$.

Following statistical analysis and interpretation, the cardinal orientation did not significantly influence the diameter and height of the plants of Heuchera $x$ hybrida 'Fire Alarm' ( $p$ value $>0.05$ ). In contrast, the number of leaves was significantly different from one cardinal orientation to another $(p$ value $<0.05)$. The calendar month in which the data were collected significantly influenced the average values of these three parameters. 
Regarding the interaction between the two factors (calendar month and cardinal orientation) no significantly different values were noted.

The other species used, for the reasons set out in this work, are no longer of interest to this experiment.

Author Contributions: Conceptualization, M.C., E.L.C. and C.C.; methodology, M.C. and E.L.C.; software, C.C.; validation, E.L.C.; formal analysis, C.C.; investigation, M.C.; data curation, C.C.; writing-original draft preparation, M.C.; writing-review and editing, M.C., E.L.C. and C.C.; visualization, M.C.; supervision, E.L.C. All authors have read and agreed to the published version of the manuscript.

Funding: This research received no external funding.

Institutional Review Board Statement: Not applicable.

Informed Consent Statement: Not applicable.

Data Availability Statement: Some data presented in this study are available from the corresponding author, upon reasonable request.

Acknowledgments: We thank the National Meteorological Administration-Moldova Regional Meteorological Center for the climate data provided.

Conflicts of Interest: The authors declare no conflict of interest.

\section{Abbreviations}

$\begin{array}{ll}\text { C1 } & \text { Experimental structure 1 } \\ \text { C1N } & \text { Experimental structure 1, north facade } \\ \text { C1E } & \text { Experimental structure 1, east facade } \\ \text { C1S } & \text { Experimental structure 1, south facade } \\ \text { C1W } & \text { Experimental structure 1, west facade } \\ \text { C2 } & \text { Experimental structure 2 } \\ \text { P1 } & \text { Level 1 } \\ \text { P2 } & \text { Level 2 } \\ \text { P3 } & \text { Level 3 } \\ \text { P4 } & \text { Level 4 } \\ \text { NMA } & \text { National Meteorological Administration-Moldova Regional Meteorological Center }\end{array}$

\section{References}

1. Chiriac, D.; Humă, C.; Stanciu, M. Spațiile verzi—o problemă a urbanizării actuale. Calit. Vieții 2009, 249-270.

2. Francis, A.R.; Lorimer, J. Urban reconciliation ecology: The potential of living roofs and walls. J. Environ. Manag. 2011, 92, 1429-1437. [CrossRef] [PubMed]

3. Manso, M.; Castro-Gomez, J. Green wall systems: A review of their characteristics. Renew. Sustain. Energy Rev. 2015, 41, 863-871. [CrossRef]

4. Pérez, G.; Rincón, L.; Vila, A.; González, M.J.; Cabeza, L.F. Green vertical systems for buildings as passive systems for energy savings. Appl. Energy 2011, 88, 4854-4859. [CrossRef]

5. $\quad$ Perini, K.; Ottelé, M.; Fraaji, A.L.A.; Haas, E.M.; Raiteri, R. Vertical greening systems and the effect on air flow and temperature on the building envelope. Build. Environ. 2011, 46, 2287-2294. [CrossRef]

6. Pérez, G.; Rincón, L.; Vila, A.; González, M.J.; Cabeza, L.F. Behaviour of green façades in Mediterranean Continental climate. Energy Convers. Manag. 2011, 52, 1861-1867. [CrossRef]

7. Ottelé, M.; Perini, K.; Fraaij, A.L.A.; Haas, E.M.; Raiteri, R. Comparative life cycle analysis for green façades and living wall systems. Appl. Energy 2011, 43, 3419-3429. [CrossRef]

8. Ghazalli, A.J.; Brack, C.; Bai, X.; Said, I. Physical and Non-Physical Benefits of Vertical Greenery Systems: A Review. J. Urban Technol. 2019, 26, 53-78. [CrossRef]

9. Sheweka, S.M.; Nourhan, M.M. Green Façades as a New Sustainable Approach towards Climate Change. Energy Procedia 2012, 18, 507-520. [CrossRef]

10. Mårtensson, M.; Wuolo, A.; Fransson, A.M.; Emilsson, T. Plant Performance in Living Wall Systems in the Scandinavian Climate. Ecol. Eng. 2014, 71, 610-614. [CrossRef]

11. Fan, Y.; Das, K.V.; Chen, Q. Neighbourhood Green, Social Support, Physical Activity and Stress: Assessing the Cumulative Impact. Health Place 2011, 17, 1202-1211. [CrossRef] [PubMed] 
12. Leather, P.; Beale, D.; Sullivan, L. Noise, Psychosocial Stress and Their Interaction in the Workplace. J. Environ. Psychol. 2003, 23, 213-222. [CrossRef]

13. De Vries, S.; Van Dillen, S.M.; Groenewegen, P.P.; Spreeuwenberg, P. Streetscape Greenery and Health: Stress, Social Cohesion and Physical Activity as Mediators. Soc. Sci. Med. 2013, 94, 26-33. [CrossRef] [PubMed]

14. Growing Perennials. Available online: https://hgic.clemson.edu/factsheet/growing-perennials/ (accessed on 19 November 2021).

15. RHS Gardening. Available online: https://www.rhs.org.uk (accessed on 19 November 2021).

16. Chiruţă, C.; Cojocariu, M.; Călin, M.; Bulgariu, E. Use of Cloud Applications for Data Management, Processing and Interpretation in Research Teams. J. Sci. Work. Hortic. Ser. 2020, 63, 25-30.

17. Barthélémy, D.; Caraglio, Y. Plant Architecture: A Dynamic, Multilevel and Comprehensive Approach to Plant Form, Structure and Ontogeny. Ann. Bot. 2007, 99, 375-407. [CrossRef] [PubMed]

18. Nugroho, A.M. Vertical Landscape for Passive Cooling in Tropical House. Procedia Environ. Sci. 2014, 20, 141-145. [CrossRef] 